\title{
Polymorphisms in the Chicken Growth Differentiation Factor 9 Gene Associated with Reproductive Traits
}

\author{
Lingbin Liu, ${ }^{1,2}$ Zhifu Cui, ${ }^{2}$ Qihai Xiao, ${ }^{2}$ Haihan Zhang, ${ }^{3}$ Xiaoling Zhao, ${ }^{2}$ Yan Wang $\left(\mathbb{D},{ }^{2}\right.$ \\ Huadong Yin $(1),{ }^{2}$ Diyan Li $\left(\mathbb{b},{ }^{2}\right.$ and Qing Zhu ()$^{2}$ \\ ${ }^{1}$ College of Animal Science and Technology, Southwest University, Chongqing, China \\ ${ }^{2}$ Farm Animal Genetic Resources Exploration and Innovation Key Laboratory of Sichuan Province, Sichuan Agricultural University, \\ Chengdu Campus, Sichuan Province, China \\ ${ }^{3}$ Department of Animal and Poultry Sciences, Virginia Tech, Blacksburg, Virginia, USA
}

Correspondence should be addressed to Qing Zhu; zhuqingsicau@163.com

Received 12 January 2018; Accepted 2 August 2018; Published 19 September 2018

Academic Editor: Bo Zuo

Copyright (C) 2018 Lingbin Liu et al. This is an open access article distributed under the Creative Commons Attribution License, which permits unrestricted use, distribution, and reproduction in any medium, provided the original work is properly cited.

\begin{abstract}
The aim of the study was to investigate GDF9 gene polymorphisms and their association with reproductive traits in chicken using DNA sequencing. A total of 279 Dongxiang blue-shelled (DX) chickens and 232 Luhua (LH) chickens were used for validation. We detected 15 single nucleotide polymorphisms (SNPs): nine SNPs were previously unreported in chicken, two were missense mutations, and only three exhibited significant associations with reproductive traits. G.17156387C $>\mathrm{T}$ was significantly associated with age at first egg (AFE) and weight of first egg (WFE) in both breeds. Birds carrying the CC genotype exhibited higher AFE and WFE values than those with the TT genotype. The SNP g.17156427A $>$ G exhibited an association with egg weight at 300 days of age (EWTA) in DX but not in LH chickens. The SNP g.17156703A $>$ C affected the AFE and EN (total number of eggs at 300 days of age) in DX chickens. In addition, certain diplotypes significantly affected AFE, BWTA (body weight at 300 days of age), and EN in both breeds. RT-PCR results showed that the GDF9 gene was highly expressed in stroma with cortical follicles (STR) and prehierarchal follicles. These results provided further evidence that the GDF9 gene is involved in determining reproductive traits in chicken.
\end{abstract}

\section{Introduction}

In the modern poultry industry, reproductive traits of laying hens, such as age at first egg, egg number, and egg weight, are major factors of economic concern [1-4]. Studies on genes related to chicken reproductive traits are of great importance in terms of revealing genetic mechanisms affecting egg-laying performance and for breeding the laying hens with high productivity and quality. The candidate gene approach is a method used frequently for genetic dissection of complex and quantitative traits [5-9]. This method is based on using information regarding physiological and biochemical processes in the organism to select related genes and explore their relationship with phenotypes $[3,6]$. Several crucial genes in livestock and poultry have been identified using this approach, such as the sex-linked dwarf gene in chicken [10], insulin-like growth factor 2 (IGF2) in swine [11], growth differentiation factor 8 (GDF8) in sheep
[12], and diacylglycerol O-acyltransferase (DGAT1) in cattle $[13,14]$.

Growth differentiation factor 9 (GDF9), involved in growth and differentiation and secreted by oocytes, belongs to the transforming growth factor $\beta$ superfamily and plays a critical role in ovarian follicular development and ovulation rate in mammals [15]. Further studies have shown that GDF9 regulated hyaluronic acid synthesis, gonadotrophinstimulated progesterone production, cumulus expansion, and the maintenance of an optimal oocyte microenvironment through synergistic action along with BMP15 (bone morphogenetic protein 15) [16-18]. Besides granulosa cells closely adjacent to oocytes in some primates, the GDF9 gene is exclusively expressed in oocytes within the ovary of most animals [19-23]. Recently, several studies have suggested that GDF9 polymorphisms are associated with animal reproductive performance. Dag et al. [9] detected that a missense mutation (c.1111G>A) in GDF9 causing a 
TAble 1: Primer pairs used to screen the GDF9 gene for polymorphisms.

\begin{tabular}{|c|c|c|c|c|c|}
\hline $\begin{array}{l}\text { Primer pairs } \\
\text { name }\end{array}$ & Primer sequences $\left(5^{\prime}-3^{\prime}\right)$ & Binding regions & $\begin{array}{l}\text { Product size } \\
\text { (bp) }\end{array}$ & $\begin{array}{l}\text { Annealing } \\
\operatorname{Tm}\left({ }^{\circ} \mathrm{C}\right)\end{array}$ & Chr. position \\
\hline \multirow{2}{*}{ P1 } & F: GAAGCCGTAAGATGTGAA & \multirow{2}{*}{$\begin{array}{l}\text { Partial promoter region } \\
\text { and exon } 1,5^{\prime} \text { UTR }\end{array}$} & \multirow[t]{2}{*}{701} & \multirow[t]{2}{*}{51.5} & \multirow[t]{2}{*}{$17156010-17156720$} \\
\hline & R: GGAAGAAAGCCAGTGAAT & & & & \\
\hline \multirow[t]{2}{*}{ P2 } & F: CCTGAGAAGCAGCGTTTG & \multirow[t]{2}{*}{ Exon 1, partial intron 1} & \multirow[t]{2}{*}{796} & \multirow[t]{2}{*}{58.7} & \multirow[t]{2}{*}{ 17156430-17157225 } \\
\hline & R: CAGCAGCCTCCACATTTT & & & & \\
\hline \multirow{2}{*}{ P3 } & F: ATTGGTTTCTTCTGCTGCTT & \multirow{2}{*}{ Exon 2, partial intron 1} & \multirow[t]{2}{*}{882} & \multirow[t]{2}{*}{58} & \multirow[t]{2}{*}{ 17157996-17158877 } \\
\hline & R: CATAACGGTGCCCGACTA & & & & \\
\hline \multirow{2}{*}{$\mathrm{P} 4$} & F: AACACGCAGGGCAAAAGG & \multirow{2}{*}{ Exon 2} & \multirow[t]{2}{*}{971} & \multirow[t]{2}{*}{54.2} & \multirow[t]{2}{*}{ 17158631-17159601 } \\
\hline & R: AAGTCCCGACCAAAGCAG & & & & \\
\hline \multirow{2}{*}{ P5 } & F: TCTGGGAAAAGAGGAAAG & \multirow{2}{*}{ Partial $3^{\prime}$ UTR } & \multirow[t]{2}{*}{711} & \multirow[t]{2}{*}{46} & \multirow[t]{2}{*}{ 17159411-17160111 } \\
\hline & R: GTCTGAAATGGGTTGGTG & & & & \\
\hline
\end{tabular}

Val $\longrightarrow$ Met substitution was significantly associated with litter size in sheep. The $F e c G^{E}$ allele of a novel GDF9 polymorphism significantly increased ovulation rate and prolificacy in sheep [24]. Additionally, GDF9 polymorphisms have also shown significant correlations with high prolificacy in goats $[8,25]$, the number of transferable embryos and ova in cows [26], and sperm quality traits in bulls [27]. However, most studies implicating effects of GDF9 on reproductive performance have been conducted in mammals, and there are limited data regarding its role in the reproductive system of poultry.

Thus, we hypothesized that the GDF9 gene was involved in the reproductive traits of laying hens. Single nucleotide polymorphisms (SNPs) are DNA sequence polymorphisms resulting from variation of a single nucleotide at the genomic level, including insertions, deletions, transversions, and transitions. SNPs comprise the latest generation of genetic markers and are often applied in animal breeding programs owing to their advantages such as high frequency, stability, and ease of genotyping $[6,28,29]$. To validate our hypothesis, in this study, we identified chicken GDF9 SNPs via pooled DNA sequencing and investigated these SNPs association with reproductive traits in Luhua chicken and Dongxiang blueshelled chicken. Furthermore, we analyzed expression levels of GDF9 mRNA in different chicken tissues and different breeds using quantitative real-time PCR.

\section{Materials and Methods}

2.1. Chicken Populations and Phenotypic Traits. Two chicken populations, Luhua chickens $(\mathrm{LH}, \mathrm{N}=232)$ and Dongxiang blue-shelled chickens (DX, N = 279), were used to assess the relationships between screened SNPs and reproductive traits. LH chickens are commercial egg-layers originating from the American Plymouth Rock and exhibit high egg productivity $[4,30]$. DX chicken is an indigenous chicken breed from China that lays blue-shelled eggs with low egg productivity $[31,32]$. Blue-shelled eggs are gaining popularity among consumers in some countries due to their high protein and low cholesterol contents [32]. Birds were reared in the poultry farm of Sichuan Agricultural University (Sichuan, China), and feed protocols and conditions followed those in previous research [33]. Six reproductive traits that are conventional selection indices in breeding programs for laying hens $[3,16$, 34] were measured: age at first egg (AFE), body weight at first egg (BWFE), weight of first egg (WFE), body weight at 300 days of age (BWTA), egg weight at 300 days of age (EWTA), and total number of eggs at 300 days of age (EN). Blood samples were collected from the wing veins of all chickens. Genomic DNA was isolated using the phenol-chloroform extraction method following standard procedures [35], dissolved in TE buffer, and stored at $-20^{\circ} \mathrm{C}$. All animal care and experimental procedures were approved by the Institutional Animal Care and Use Committee of Sichuan Agricultural University (No. YYS130125). All research work was conducted in strict accordance with the Sichuan Agricultural University (SAU) Laboratory Animal Welfare and Ethics guidelines [36].

2.2. SNP Discovery and Genotyping. Discovery of GDF9 gene polymorphisms and their association with reproductive traits in chickens was based on pooled DNA sequencing. Five primer pairs (P1-P5, Table 1) for amplifying and sequencing were designed with Primer Premier 5.0 (PREMIER Biosoft International, CA, USA) using the complete DNA sequence of the GDF9 gene (Genbank accession number: NC_006100.4). Firstly, a pooled DNA sample containing 80 ng DNA from 60 chickens (30 birds from each breed) was constructed to identify SNPs. SNPs in PCR products were identified on the basis of multiple peaks at the same base position in sequencing results. Next, primer pairs producing SNP-containing PCR products were amplified using DNA from all birds (232 LH chickens and 279 DX chickens). Finally, eliminating low frequency SNPs $(<1 \%)$, we further investigated the relationship between these SNPs and reproductive traits in LH chickens and DX chickens.

All PCR amplifications were carried out using a PT-100 thermal cycler (MJ Research, USA) in a volume of $50 \mu \mathrm{L}$, including $12 \mu \mathrm{L}$ of distilled $\mathrm{H}_{2} \mathrm{O}, 25 \mu \mathrm{L}$ of $2 \times$ Taq PCR Master Mix (Tiangen, China), $4 \mu \mathrm{L}$ of each primer $(10 \mathrm{nmol} / \mathrm{L})$, and 80 ng DNA template. PCR cycling conditions were as follows: $95^{\circ} \mathrm{C}$ for $5 \mathrm{~min}$ followed by 35 cycles of $95^{\circ} \mathrm{C}$ for 40 $\mathrm{s}, 51-59^{\circ} \mathrm{C}$ (depending on the primer pair, Table 1) for $40 \mathrm{~s}$, and $72^{\circ} \mathrm{C}$ for $40 \mathrm{~s}$ and a full extension cycle at $72^{\circ} \mathrm{C}$ for 8 min. All PCR products were purified and sequenced using an ABI 3730 automated sequencer by a commercial sequencing 
TABLE 2: Summary of variations in the chicken GDF9 gene.

\begin{tabular}{|c|c|c|c|c|c|}
\hline Primer pairs no. & Variations & Chr. position & Gene region & Amino acid position & Function \\
\hline $\mathrm{P} 1$ & g. $17156328 \mathrm{G}>\mathrm{T}$ & 17156328 & Promoter region & & \\
\hline $\mathrm{P} 1$ & g. $17156387 \mathrm{C}>\mathrm{T}$ & 17156387 & Promoter region & & \\
\hline P1 & g.17156427A >G & 17156427 & Promoter region & & \\
\hline $\mathrm{P} 2$ & g. $17156703 \mathrm{~A}>\mathrm{C}$ & 17156703 & Exon 1 & 15 & Missense \\
\hline P3 & g.17158286A $>G$ & 17158286 & Exon 2 & 198 & Missense \\
\hline $\mathrm{P} 4$ & g.17158915T $>C$ & 17158915 & Exon 2 & 407 & Synonymous \\
\hline P4 & g.17159060T $>C$ & 17159060 & $3^{\prime}$ UTR & & \\
\hline P5 & g. $17159524 \mathrm{~A}>\mathrm{T}$ & 17159524 & $3^{\prime}$ UTR & & \\
\hline P5 & g. $17159575 \mathrm{C}>\mathrm{T}$ & 17159575 & $3^{\prime}$ UTR & & \\
\hline P5 & g.17159624T >G & 17159624 & $3^{\prime}$ UTR & & \\
\hline P5 & g. $17159625 \mathrm{~T}>\mathrm{C}$ & 17159625 & $3^{\prime}$ UTR & & \\
\hline P5 & g. $17159748 \mathrm{C}>\mathrm{T}$ & 17159748 & $3^{\prime}$ UTR & & \\
\hline P5 & g.17159978A $>G$ & 17159978 & $3^{\prime}$ UTR & & \\
\hline P5 & g.17160044T >C & 17160044 & $3^{\prime}$ UTR & & \\
\hline P5 & g.17160047G $>A$ & 17160047 & $3^{\prime}$ UTR & & \\
\hline
\end{tabular}

UTR means untranslated region.

facility (Sangon, Shanghai, China). All sequences were visually inspected, edited, assembled, and aligned using the software DNASTAR (DNASTAR Inc., USA). Haploview [37] was used to estimate linkage disequilibrium among SNP pairs. Pearson's chi-square test was used to determine whether polymorphisms in the sample population were under HardyWeinberg equilibrium. Haplotypes were constructed using the software PHASE [38].

2.3. Total RNA Isolation and Quantitative Real-Time PCR (qPCR). Six 30-week-old birds were randomly selected from among the DX and LH egg-laying hens and then euthanized by cervical dislocation to collect the following ovarian tissues: stroma with cortical follicles $<1 \mathrm{~mm}$ in diameter (STR), prehierarchical follicles including white follicles (WF, 1-4 mm in diameter), yellowish follicles (YF, 4-8 $\mathrm{mm}$ in diameter) and small yellow follicles (SYF, 8-12 mm in diameter), and hierarchical follicles F1-F6 (with the largest denoted as F1, the second largest as F2, etc.). All samples were submerged in RNAlater (Invitrogen, Carlsbad, CA) overnight at $4^{\circ} \mathrm{C}$ and then stored at $-80^{\circ} \mathrm{C}[39]$.

Total RNA was extracted from tissue samples with TRIzol RNA extraction reagent (TaKaRa Biotechnology Co. Ltd., Dalian, China). The concentration of total RNA was measured, its purity was validated with spectrophotometry at $260 / 280 \mathrm{~nm}$, and its integrity was evaluated by $2 \%$ agarose gel electrophoresis. The first strand of cDNA was synthesized from $1 \mu \mathrm{g}$ total RNA using the PrimeScript RT Reagent Kit Perfect Real-Time (TaKaRa), according to the manufacturer's protocol. Real-time PCR primers were designed using the partial mRNA sequence of the GDF9 gene (Genbank accession number: NM_206988.2) without SNP sites using Primer Premier 5.0 (F: 5'-TACGCCACCAAGGAGGGAA-3', R: $5^{\prime}$-AGCAAATCCACCGAGTGAAAGT$3^{\prime}$ ). The $\beta$-actin gene (Genbank accession number: NM_205518.1) was used as the endogenous control for normalization, and the primer sequences were as follows: forward primer $\left(5^{\prime}\right.$-GAGAAATTGTGCGTGACATCA-3') and reverse primer $\left(5^{\prime}-\mathrm{CCTGAACCTCTCATTGCCA-3^{ \prime }}\right)$. A total volume of $15 \mu \mathrm{L}$ in each reaction included $7.5 \mu \mathrm{L}$ of $2 \times$ SYBR Green SuperMix (Bio-Rad, Inc., Hercules, CA, USA), $0.6 \mu \mathrm{L}$ each of $10 \mu \mathrm{M}$ forward and reverse primers, 1 $\mu \mathrm{L}$ of $\mathrm{cDNA}$, and $5.3 \mu \mathrm{L}$ of RNase-free water. Real-time PCR reactions were performed in triplicate on a CFX96 qPCR system (Bio-Rad). The cycling conditions were as follows: $95^{\circ} \mathrm{C}$ for $30 \mathrm{~s}$, followed by 40 cycles of $95^{\circ} \mathrm{C}$ for $5 \mathrm{~s}$, a variable annealing temperature ( $\beta$-actin: $61^{\circ} \mathrm{C}$, and GDF9: $\left.64.5^{\circ} \mathrm{C}\right)$ for $30 \mathrm{~s}$, and $72^{\circ} \mathrm{C}$ for $10 \mathrm{~s}$. The melting curve was determined and analyzed at $65-95^{\circ} \mathrm{C}$. The amplification efficiencies of target genes ranged from $95 \%$ to $105 \%$.

2.4. Statistical Analysis. Associations between GDF9 polymorphisms and reproductive traits and expression levels were evaluated using SAS 9.0 (SAS Institute Inc., Cary, NC, USA). The relationship between polymorphisms and reproductive traits in each population was modeled as follows: $\mathrm{Y}_{\mathrm{ij}}=\mu$ $+G_{i}+B_{j}+(G B)_{i j}+e_{i j}$, where $Y_{i j}$ is the observation value for the trait; $\mu$ is the population mean of the trait; $G_{i}$ is the fixed effect of the genotype or diplotype; $B_{j}$ is the fixed effect of the breed; $(\mathrm{GB})_{\mathrm{ij}}$ is the interaction effect of the genotype or diplotype based on breed; and $\mathrm{e}_{\mathrm{ij}}$ is the residual error. The quantification of relative mRNA expression was performed using the $2^{-\Delta \Delta \mathrm{Ct}}$ method. Statistical significance was determined by the general linear model and further analyzed using Tukey's multiple comparison test. Results are presented as least square means \pm SEM, and differences were considered significant at $P<0.05$.

\section{Results}

3.1. GDF9 SNP Identification. The chicken GDF9 gene is located on chromosome 13 and comprises two exons and one intron. We amplified and sequenced all exons, and parts of the intron and untranslated regions (UTR) of chicken GDF9 gene (Table 1). A total of 15 SNPs were detected by performing DNA sequencing of all chickens (Table 2) and included nine 


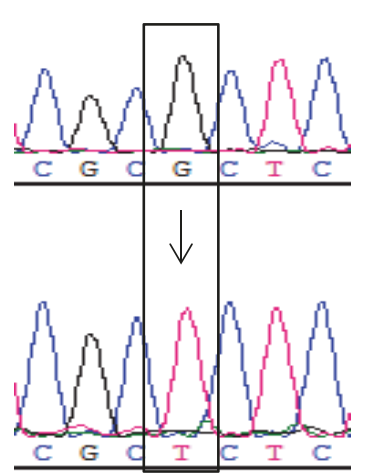

g.17156328G $>\mathrm{T}$

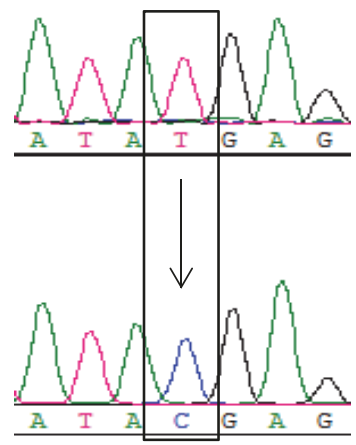

g.17158915T $>C$

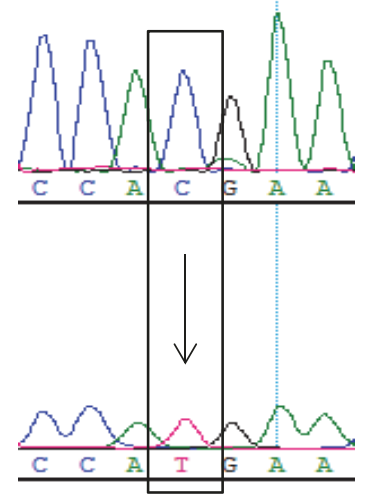

g.17156387C $>\mathrm{T}$

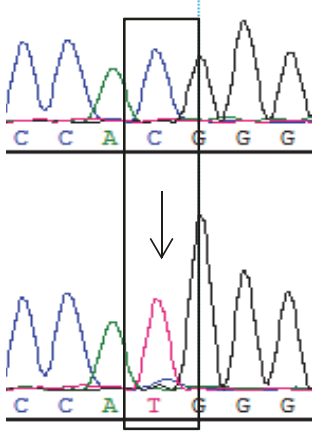

g.17159748C $>\mathrm{T}$

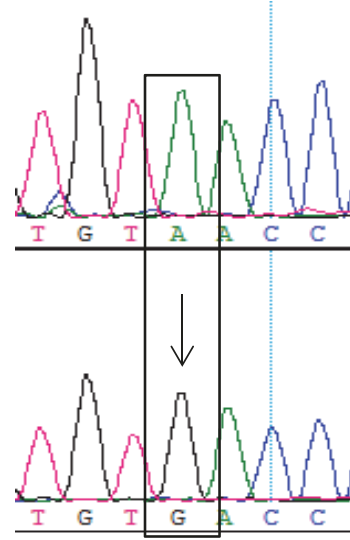

g.17156427A $>$ G

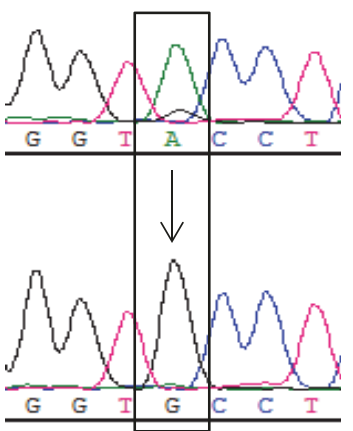

g.17159978A $>\mathrm{G}$

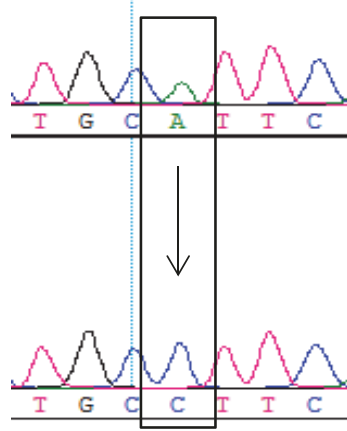

g.17156703A $>C$

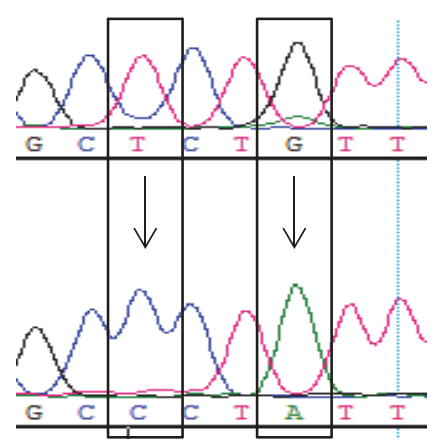

g.17160044T $>C$ and g.17160047G $>A$

FIGURE 1: Nine previously unreported SNPs in chicken GDF9 gene. Arrows indicate mutation sites.

SNPs previously unreported in chicken, as shown in Figure 1. Among these polymorphic sites, three SNPs were located in the promoter region, one in exon 1, two in exon 2, and nine in the $3^{\prime}$ UTR. Among the exonic SNPs, two (g.17156703A >C and g.17158286A $>\mathrm{G}$ ) were missense mutations, resulting in the amino acids substitutions of Ile $\longrightarrow$ Leu and Ile $\longrightarrow$ Val, respectively. Two SNPs (g.17159637T $>$ G and g.17159638T >C) were found to be completely linked $\left(D^{\prime}=1.0\right.$, and $\left.r^{2}=1.0\right)$; all other pairs of SNPs showed low LD values $\left(D^{\prime}=0.081 \sim 0.316\right.$, and $r^{2}=0.005 \sim 0.278$ ).

The results of association analysis in all chickens showed that g.17156387C $>$ T, g.17156427A $>$ G, and g.17156703A $>C$ were significantly associated with some reproductive traits $(P<0.05)$ (Table 3). Meanwhile, no significant associations were detected between other SNPs and any of the chicken reproductive traits (Table 3 ). Therefore, the following analysis including determining genotype frequency and performing detailed association analysis were only performed for the three SNPs.

\subsection{Relationships between Genotypes and Reproductive Traits.} Results of genotype frequency analysis of the three SNPs were summarized in Table 4. Genotype frequency of these SNPs showed similar patterns, with the frequency of homozygous mutations being the lowest. Next, we evaluated the effect of the SNP g.17156387C>T (Table 5). The polymorphism of g.17156387C $>\mathrm{T}$ was significantly associated with AFE (0.04) and WFE (0.03). Birds carrying the CC genotype exhibited higher AFE and WFE values than those with the TT genotype. As shown in Table 6, the SNP g.17156427A>G only exhibited an association with EWTA $(P=0.03)$, and there was an interaction $(P=0.008)$ of genotype and breed where the genetic effect was associated with EWTA in DX but not LH chickens. Homozygous laying hens presenting the GG genotype have shown a significant increase in EWTA (56.92 g) compared to birds with the AA (50.27 g) and AG (51.56 g) genotypes in DX chickens $(P<0.05)$ (Figure $2(\mathrm{a}))$. The final GDF9 SNP to be assessed was g.17156703A $>C$ in exon 1 which showed significant effects on AFE (0.01) (Table 7). Some interactions of genotype and breed were also found in $\operatorname{AFE}(P=0.02)$ and $\operatorname{EN}(P=0.04)$. The polymorphism had a significant genetic effect on AFE and EN in DX hens $(P<$ 0.05); birds with the AA genotype had lower AFE and higher EN values compared to those with other genotypes (Figures 2(b) and 2(c)). Meanwhile, this SNP had no effect on any of reproductive traits in $\mathrm{LH}$ chickens (Figure 2).

3.3. Relationships between Diplotypes and Reproductive Traits. A total of 19 diplotypes were identified in the present study, and eight diplotypes with frequencies more than 
TABLE 3: Association of GDF9 polymorphisms with reproductive traits in all chickens.

\begin{tabular}{|c|c|c|c|c|c|c|}
\hline \multirow[t]{2}{*}{ Polymorphism } & \multicolumn{6}{|c|}{ Traits ( $P$-value of significance test) } \\
\hline & AFE & BWFE & WFE & BWTA & EWTA & $\mathrm{EN}$ \\
\hline g.17156328G $>\mathrm{T}$ & 0.29 & 0.08 & 0.15 & 0.05 & 0.09 & 0.32 \\
\hline g.17156387C>T & $0.04 *$ & 0.16 & $0.03 *$ & 0.78 & 0.49 & 0.42 \\
\hline g.17156427A>G & 0.6 & 0.58 & 0.54 & 0.98 & $0.03 *$ & 0.69 \\
\hline g. $17156703 \mathrm{~A}>\mathrm{C}$ & $0.01 *$ & 0.41 & 0.82 & 0.14 & 0.78 & 0.16 \\
\hline g. $17158286 A>G$ & 0.60 & 0.44 & 0.15 & 0.13 & 0.21 & 0.13 \\
\hline g.17158915T >C & 0.36 & 0.47 & 0.36 & 0.08 & 0.21 & 0.15 \\
\hline g.17159060T>C & 0.52 & 0.60 & 0.47 & 0.47 & 0.29 & 0.47 \\
\hline g.17159524A >T & 0.07 & 0.55 & 0.12 & 0.12 & 0.10 & 0.30 \\
\hline g. $17159575 \mathrm{C}>\mathrm{T}$ & 0.20 & 0.73 & 0.11 & 0.13 & 0.19 & 0.06 \\
\hline g.17159624T>G & 0.09 & 0.20 & 0.43 & 0.61 & 0.11 & 0.20 \\
\hline g.17159625T>C & 0.10 & 0.20 & 0.08 & 0.41 & 0.24 & 0.52 \\
\hline g. $17159748 \mathrm{C}>\mathrm{T}$ & 0.46 & 0.08 & 0.09 & 0.14 & 0.23 & 0.08 \\
\hline g. $17159978 A>G$ & 0.20 & 0.13 & 0.05 & 0.30 & 0.08 & 0.30 \\
\hline g. $17160044 \mathrm{~T}>\mathrm{C}$ & 0.67 & 0.08 & 0.28 & 0.41 & 0.14 & 0.15 \\
\hline g. $17160047 \mathrm{G}>\mathrm{A}$ & 0.31 & 0.18 & 0.51 & 0.22 & 0.26 & 0.13 \\
\hline
\end{tabular}

$\mathrm{AFE}=$ age at first egg, BWFE = body weight at first egg, WFE = weight of first egg, BWTA = body weight at 300 days of age, EWTA $=$ egg weight at 300 days of age, and $\mathrm{EN}=$ total number of eggs at 300 days of age.

* Significant association $(P<0.05)$.

TABLE 4: Genotype frequencies in three SNPs of GDF9.

\begin{tabular}{lcccc}
\hline SNP & Genotype & ALL & LH & DX \\
\hline g.17156387C $>$ T & CC & $0.62(317)$ & $0.81(188)$ & $0.46(129)$ \\
& CT & $0.33(166)$ & $0.17(38)$ & $0.46(128)$ \\
& TT & $0.05(28)$ & $0.02(6)$ & $0.08(22)$ \\
\hline g.17156427A $>$ G & AA & $0.60(304)$ & $0.41(94)$ & $0.75(210)$ \\
& AG & $0.32(165)$ & $0.44(102)$ & $0.23(63)$ \\
& GG & $0.08(42)$ & $0.15(36)$ & $0.02(6)$ \\
\hline g.17156703A $>$ C & AA & $0.37(188)$ & $0.32(73)$ & $0.41(115)$ \\
& AC & $0.45(231)$ & $0.45(105)$ & $0.45(126)$ \\
& CC & $0.18(92)$ & $0.23(54)$ & $0.14(38)$ \\
\hline
\end{tabular}

LH means Luhua chickens $(\mathrm{N}=232)$, DX means Dongxiang blue-shelled chickens $(\mathrm{N}=279)$, and ALL means the sum of the number of LH and DX chickens $(\mathrm{N}=511)$.

0.02 were selected from each breed to further evaluate associations with chicken reproductive traits (Table 8). The results showed that certain diplotypes significantly affected AFE (0.01), BWTA (0.04), and EN (0.04). Birds with the diplotype D2 (CCAAAC) exhibited the highest EN value, and those with D7 (CTAAAA) had the lowest AFE and BWTA values (Table 9). In addition, there were several differences between the two breeds with respect to all reproductive traits (Tables 5-7 and 9). BWFE, WFE, BWTA, EWTA, and EN were greater in LH than in DX chickens $(P<$ $0.05)$, whereas AFE was greater in DX than in LH chickens $(P<0.05)$.

3.4. Expression of GDF9 in Reproductive Tissues. In both breeds, the GDF9 mRNA was most abundant in the STR, and all prehierarchical follicles (WF, YF, and SYF) exhibited higher expression of the GDF9 gene than the hierarchical follicles (F1-F6). Moreover, GDF9 mRNA expression was significantly higher in the STR, SYF, and F6 of LH chickens than in the corresponding tissues of DX chickens $(P<0.05)$ (Figure 3).

\section{Discussion}

4.1. Polymorphisms in the GDF9 Gene. Numerous studies have shown that GDF9 is a candidate gene involving reproductive performance and plays a critical role in animal reproductive biology [40-43]. However, the majority of these reports on the relationship between GDF9 polymorphisms and reproductive traits have focused on swine, sheep, and goats. Zhang et al. [7] found 12 polymorphisms including three SNPs in coding regions and one 314-bp indel in the noncoding region of the swine GDF9 gene. Hanrahan et al. [40] reported eight SNPs in the GDF9 coding region through direct sequencing of Cambridge and Belclare sheep DNA, three of which were nonsense mutations and four of which were G>A mutations. Dong et al. [44] detected four SNPs in the coding sequence of goat GDF9, comprising C183A, C719T, A959C, and G1189A. Aside from C183A, these SNPs all resulted in a change in the encoded amino acid. In the present study, we sequenced the complete coding regions of the chicken GDF9 gene and detected 15 SNPs including three located in the promoter region, one in exon 1, two in exon 2, and nine in the $3^{\prime}$ UTR. Among these, nine SNPs were previously unreported in chicken; two coding sequence SNPs were missense mutations, resulting in the amino acids substitutions of Ile $\longrightarrow$ Leu and Ile $\longrightarrow$ Val, respectively. These results significantly broaden our current understanding of GDF9 polymorphisms underlying the reproductive systems of laying hens. 
TABLE 5: Association analysis between GDF9 g.17156387C > T genotypes and reproductive traits.

\begin{tabular}{|c|c|c|c|c|c|c|}
\hline & AFE (days) & BWFE (g) & WFE (g) & BWTA (g) & EWTA (g) & EN (count) \\
\hline \multicolumn{7}{|l|}{ Genotype } \\
\hline $\mathrm{CC}$ & $165.85 \pm 0.96^{\mathrm{a}}$ & $1799.65 \pm 27.46$ & $44.13 \pm 0.67^{\mathrm{a}}$ & $1722.41 \pm 19.19$ & $58.33 \pm 0.61$ & $98.53 \pm 1.48$ \\
\hline $\mathrm{CT}$ & $161.97 \pm 1.51^{\mathrm{b}}$ & $1482.07 \pm 42.82$ & $35.72 \pm 1.17^{\mathrm{b}}$ & $1594.05 \pm 35.9$ & $53.11 \pm 0.8$ & $103.81 \pm 2.56$ \\
\hline TT & $162.13 \pm 2.04^{\mathrm{ab}}$ & $1566.25 \pm 189.39$ & $38.33 \pm 3.52^{\mathrm{ab}}$ & $1650.63 \pm 127.14$ & $55.61 \pm 2.18$ & $102.63 \pm 5.28$ \\
\hline $\mathrm{P}$ Value & 0.04 & 0.16 & 0.03 & 0.78 & 0.49 & 0.42 \\
\hline \multicolumn{7}{|l|}{ Breed } \\
\hline LH & $161.31 \pm 0.84^{\mathrm{b}}$ & $2038.52 \pm 34.38^{\mathrm{a}}$ & $46.77 \pm 1.45^{\mathrm{a}}$ & $1869.7 \pm 44.75^{\mathrm{a}}$ & $61.93 \pm 0.94^{\mathrm{a}}$ & $112.65 \pm 2.84^{\mathrm{a}}$ \\
\hline DX & $165.61 \pm 1.21^{\mathrm{a}}$ & $1305.22 \pm 26.25^{\mathrm{b}}$ & $34.08 \pm 1.11^{\mathrm{b}}$ & $1503.48 \pm 34.21^{\mathrm{b}}$ & $50.65 \pm 0.72^{\mathrm{b}}$ & $84.91 \pm 2.17^{\mathrm{b}}$ \\
\hline P Value & 0.008 & $<0.0001$ & $<0.0001$ & $<0.0001$ & $<0.0001$ & $<0.0001$ \\
\hline \multicolumn{7}{|l|}{$\mathrm{GxB}$} \\
\hline $\mathrm{P}$ Value & 0.06 & 0.1 & 0.47 & 0.39 & 0.54 & 0.64 \\
\hline
\end{tabular}

$\mathrm{AFE}=$ age at first egg, BWFE = body weight at first egg, WFE = weight of first egg, BWTA = body weight at 300 days of age, EWTA = egg weight at 300 days of age, and $\mathrm{EN}=$ total number of eggs at 300 days of age.

LH means Luhua chickens ( $\mathrm{N}=232)$, and DX means Dongxiang blue-shelled chickens $(\mathrm{N}=279)$.

Results are expressed as least square means \pm standard errors.

Different letters indicate significant differences $(P<0.05)$.

TABLE 6: Association analysis between GDF9 g.17156427A>G genotypes and reproductive traits.

\begin{tabular}{|c|c|c|c|c|c|c|}
\hline & AFE (days) & BWFE (g) & WFE (g) & BWTA (g) & EWTA (g) & EN (count) \\
\hline \multicolumn{7}{|l|}{ Genotype } \\
\hline AA & $163.38 \pm 1.19$ & $1616.7 \pm 34.69$ & $43.75 \pm 0.84$ & $1641.09 \pm 24.31$ & $55.35 \pm 0.66^{\mathrm{b}}$ & $98.45 \pm 1.89$ \\
\hline AG & $161.5 \pm 1.09$ & $1793.75 \pm 40.97$ & $42.97 \pm 1.03$ & $1737.36 \pm 28.84$ & $59.04 \pm 0.73^{\mathrm{ab}}$ & $105.09 \pm 2.08$ \\
\hline GG & $162.36 \pm 2.11$ & $1853.18 \pm 55$ & $41.54 \pm 1.79$ & $1734.09 \pm 43.04$ & $60.83 \pm 1.16^{\mathrm{a}}$ & $103.44 \pm 3.56$ \\
\hline$P$-value & 0.6 & 0.58 & 0.54 & 0.98 & 0.03 & 0.69 \\
\hline \multicolumn{7}{|l|}{ Breed } \\
\hline LH & $159.52 \pm 0.74^{b}$ & $1996.03 \pm 15.49^{\mathrm{a}}$ & $46.96 \pm 0.67^{\mathrm{a}}$ & $1815.86 \pm 18.21^{\mathrm{a}}$ & $61.98 \pm 0.39^{a}$ & $114.59 \pm 1.18^{\mathrm{a}}$ \\
\hline DX & $166.51 \pm 1.41^{\mathrm{a}}$ & $1336.56 \pm 15.48^{\mathrm{b}}$ & $34.85 \pm 0.66^{\mathrm{b}}$ & $1519.62 \pm 22.62^{b}$ & $50.86 \pm 0.41^{b}$ & $86.02 \pm 1.41^{\mathrm{b}}$ \\
\hline$P$-value & 0.0009 & $<0.0001$ & $<0.0001$ & $<0.0001$ & $<0.0001$ & $<0.0001$ \\
\hline \multicolumn{7}{|l|}{$\mathrm{G} \times \mathrm{B}$} \\
\hline$P$-value & 0.49 & 0.31 & 0.99 & 0.49 & 0.008 & 0.44 \\
\hline
\end{tabular}

$\mathrm{AFE}=$ age at first egg, BWFE = body weight at first egg, WFE = weight of first egg, BWTA = body weight at 300 days of age, EWTA = egg weight at 300 days of age, and $\mathrm{EN}=$ total number of eggs at 300 days of age.

LH means Luhua chickens $(\mathrm{N}=232)$, and DX means Dongxiang blue-shelled chickens $(\mathrm{N}=279)$.

Results are expressed as least square means \pm standard errors.

Different letters indicate significant differences $(P<0.05)$.

TABLE 7: Association analysis between GDF9 g.17156703A>C genotypes and reproductive traits.

\begin{tabular}{|c|c|c|c|c|c|c|}
\hline & AFE (days) & BWFE (g) & WFE (g) & BWTA (g) & EWTA $(\mathrm{g})$ & EN (count) \\
\hline \multicolumn{7}{|l|}{ Genotype } \\
\hline $\mathrm{AA}$ & $160.57 \pm 0.85^{b}$ & $1635.1 \pm 38.09$ & $40.89 \pm 1.04$ & $1634.25 \pm 27.78$ & $55.73 \pm 0.69$ & $103.35 \pm 1.82$ \\
\hline $\mathrm{AC}$ & $163.52 \pm 0.69^{\mathrm{a}}$ & $1780.47 \pm 51.69$ & $42.57 \pm 1.33$ & $1753.84 \pm 32.22$ & $57.88 \pm 1.19$ & $102.95 \pm 2.89$ \\
\hline $\mathrm{CC}$ & $163.95 \pm 1.24^{\mathrm{a}}$ & $1754.09 \pm 42.14$ & $41.95 \pm 0.88$ & $1714.02 \pm 27.72$ & $57.64 \pm 0.9$ & $101.31 \pm 2.51$ \\
\hline$P$-value & 0.01 & 0.41 & 0.82 & 0.14 & 0.78 & 0.16 \\
\hline \multicolumn{7}{|l|}{ Breed } \\
\hline $\mathrm{LH}$ & $160.21 \pm 0.69^{\mathrm{b}}$ & $1996.11 \pm 15.11^{\mathrm{a}}$ & $46.83 \pm 0.64^{\mathrm{a}}$ & $1816.94 \pm 19.42^{\mathrm{a}}$ & $62.01 \pm 0.41^{\mathrm{a}}$ & $114.89 \pm 1.16^{\mathrm{a}}$ \\
\hline DX & $164.25 \pm 1.18^{\mathrm{a}}$ & $1343.39 \pm 19.07^{\mathrm{b}}$ & $35.01 \pm 0.82^{\mathrm{b}}$ & $1547.98 \pm 24.52^{\mathrm{b}}$ & $50.01 \pm 0.52^{\mathrm{b}}$ & $84.94 \pm 1.45^{\mathrm{b}}$ \\
\hline$P$-value & $<0.0001$ & $<0.0001$ & $<0.0001$ & $<0.0001$ & $<0.0001$ & $<0.0001$ \\
\hline \multicolumn{7}{|l|}{$\mathrm{G} \times \mathrm{B}$} \\
\hline$P$-value & 0.02 & 0.37 & 0.19 & 0.21 & 0.35 & 0.04 \\
\hline
\end{tabular}

$\mathrm{AFE}=$ age at first egg, BWFE = body weight at first egg, WFE = weight of first egg, BWTA = body weight at 300 days of age, EWTA = egg weight at 300 days of age, and EN = total number of eggs at 300 days of age. LH means Luhua chickens $(\mathrm{N}=232)$, and DX means Dongxiang blue-shelled chickens $(\mathrm{N}=279)$.

Results are expressed as least square means \pm standard errors.

Different letters indicate significant differences $(P<0.05)$. 


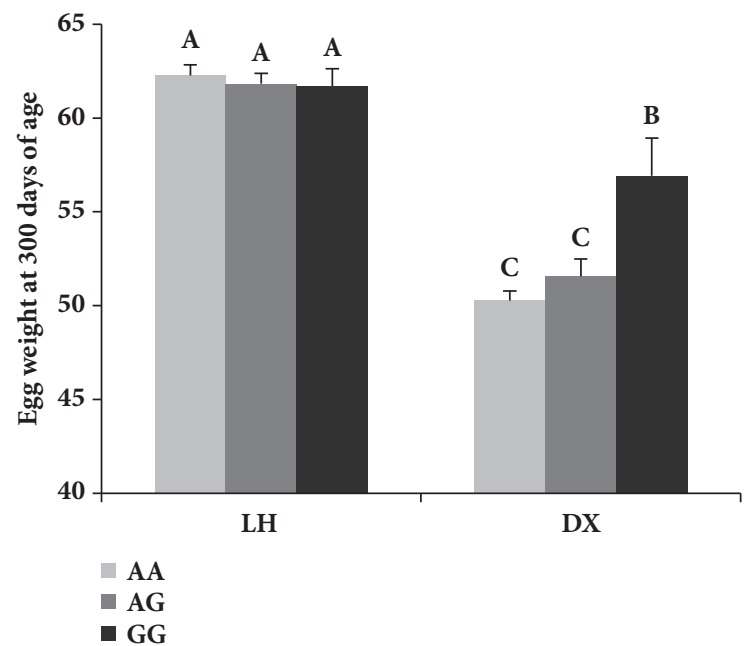

(a)

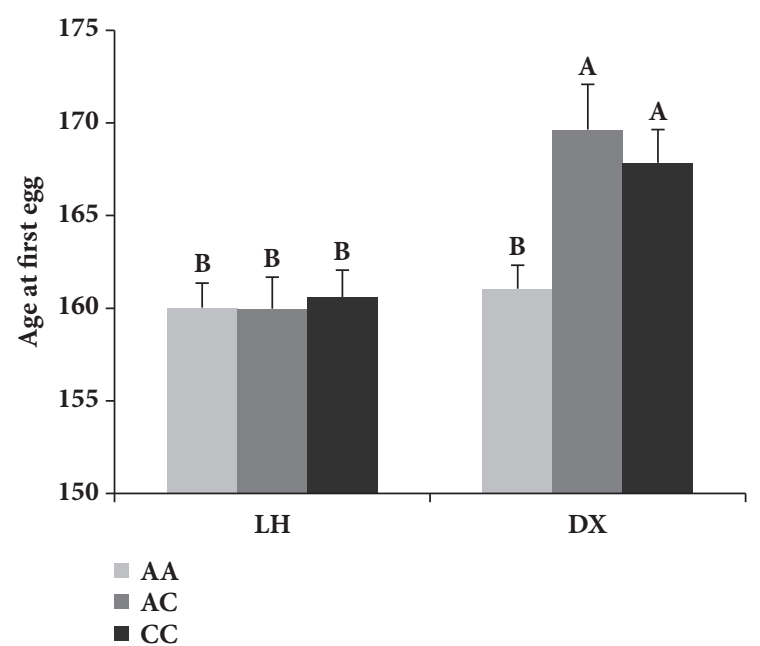

(b)

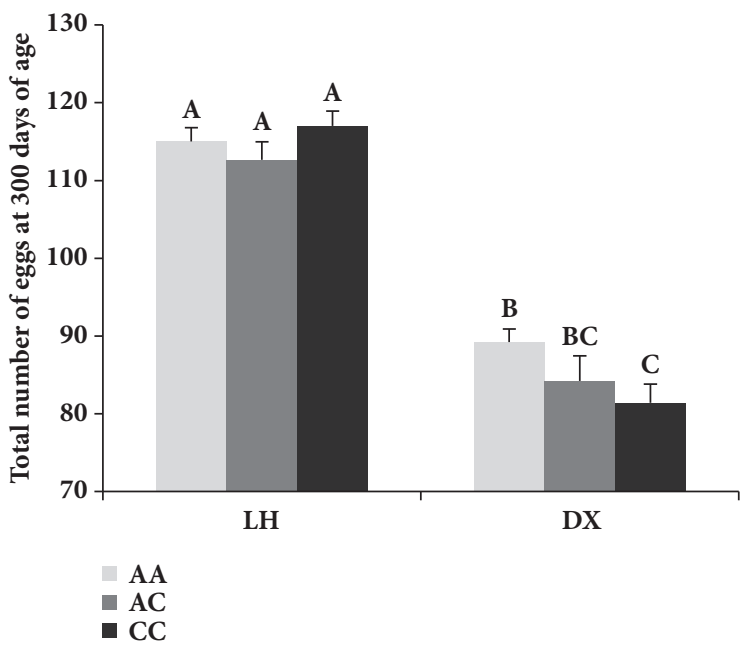

(c)

FIGURE 2: Effect of interactions between genotype and breed on (a) egg weight at 300 days of age (EWTA) in the case of the SNP g.17156427A $>$ G and (b) age at first egg (AFE) and (c) total number of eggs at 300 days of age (EN) in the case of the SNP g.17156703A $>$ C.

\subsection{Association between GDF9 and Chicken Reproduction} Traits. Several different types of mutations and polymorphisms in GDF9 have been reported to cause significant negative effects inducing infertility, ovulation impairment, and susceptibility to premature ovarian failure in some mammalian species [40, 42, 45]. In addition, positive effects on the ovulation rate in sheep and cows have been reported [24, $26,46]$, and an increase in occurrence of dizygotic twins was reported in humans [47]. In this study, three mutations were found to have effects on reproductive traits. There are several possible mechanisms underlying this relationship. Promoter regions specifically identify and bind to transcription factors that recruit RNA polymerase, controlling the initiation of transcription and gene expression [48]. The two mutations located in the GDF9 promoter region could influence transcriptional efficiency and subsequently alter the gene expression level. In the case of the SNP g.17156703A>C, it caused the amino acid substitution of Ile $\longrightarrow$ Leu, which may subsequently result in a change of function in the GDF9 protein.

In our study, BWFE, WFE, BWTA, EWTA, and EN were greater in LH than in DX chickens, whereas AFE was greater in DX than in LH chickens. This provided valuable evidence for differences in reproductive traits between the two breeds. We performed further association analyses and found that three SNPs affected several reproductive traits in DX hens, whereas only g. $17156387 \mathrm{C}>\mathrm{T}$ was significantly associated with two reproductive traits (AFE and WFE) in LH chickens. These results indicate that GDF9 polymorphisms exert relatively stronger effects in DX than in LH chickens. Compared with LH chickens, DX chickens possess enormous potential for selective breeding because of their low productivity [30-32]. Thus, when major mutations related to reproductive traits are positively selected, DX chickens may experience greater relative genetic improvement. 


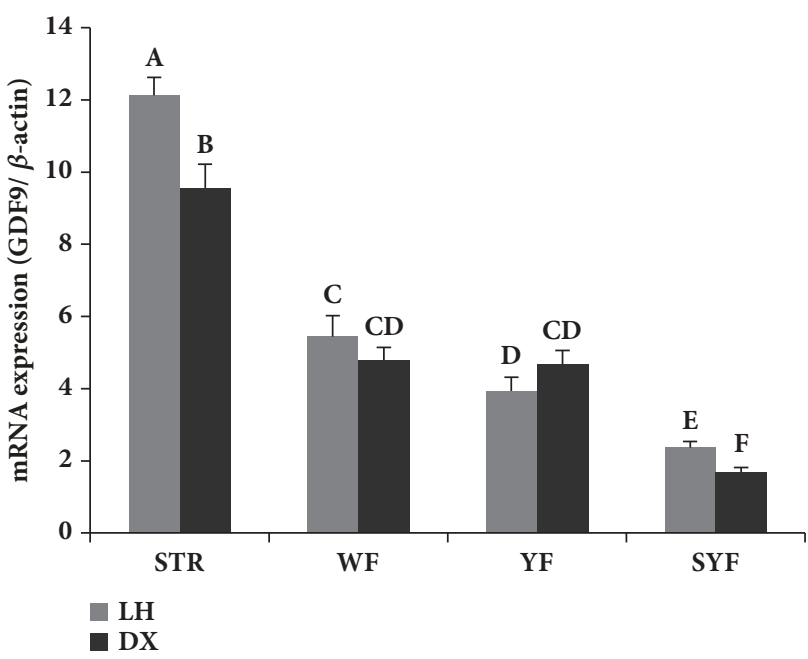

(a)

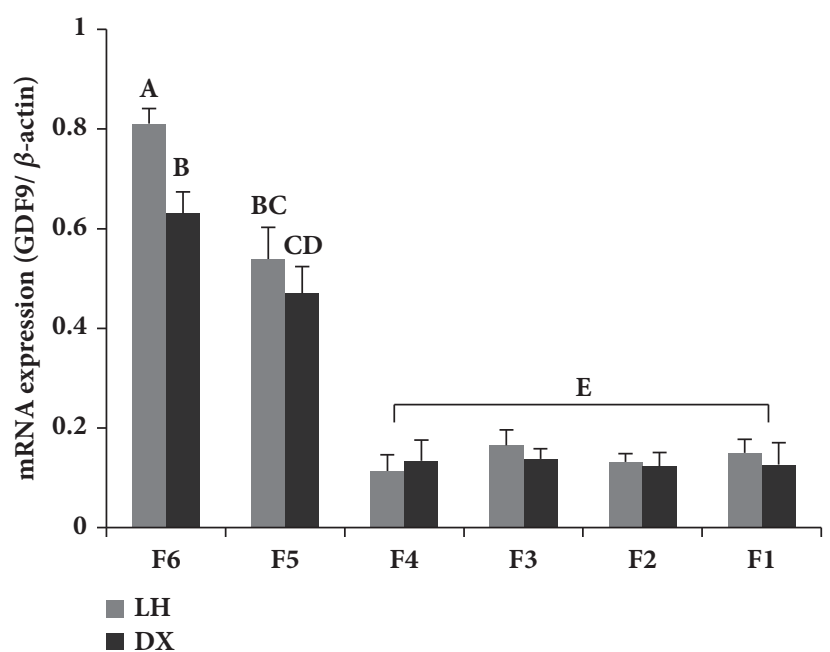

(b)

FIGURE 3: Relative expression of the GDF9 gene in the ovaries of two chicken breeds. LH = Luhua chickens, DX = Dongxiang blue-shelled chickens, STR = stroma with cortical follicles, WF = white follicles, YF = yellowish follicles, SYF = small yellow follicles, and F1-F6 = hierarchical follicles F1-F6. Results are expressed as least square means \pm standard errors. Different letters indicate significantly differences $(P<0.05)$.

TABLE 8: Diplotypes and their frequencies.

\begin{tabular}{lccc}
\hline Diplotype & ALL & LH & DX \\
\hline CCAAAA & $0.2(104)$ & $0.19(44)$ & $0.22(60)$ \\
CCAAAC & $0.06(30)$ & $0.08(18)$ & $0.04(12)$ \\
CCAACC & $0.06(33)$ & $0.05(12)$ & $0.08(21)$ \\
CCAGAA & $0.07(36)$ & $0.1(24)$ & $0.04(12)$ \\
CCAGAC & $0.07(38)$ & $0.14(32)$ & $0.02(6)$ \\
CCAGCC & $0.1(49)$ & $0.15(34)$ & $0.05(15)$ \\
CCGGAA & $0.02(8)$ & $0.03(8)$ & \\
CCGGAC & $0.01(5)$ & $0.01(2)$ & $0.01(3)$ \\
CCGGCC & $0.05(26)$ & $0.11(26)$ & \\
CTAAAA & $0.16(81)$ & $0.05(12)$ & $0.25(69)$ \\
CTAAAC & $0.04(20)$ & $0.01(2)$ & $0.06(18)$ \\
CTAACC & $0.04(20)$ & $0.01(2)$ & $0.06(18)$ \\
CTAGAA & $0.03(13)$ & $0.02(4)$ & $0.03(9)$ \\
CTAGAC & $0.01(5)$ & $0.01(2)$ & $0.01(3)$ \\
CTAGCC & $0.05(27)$ & $0.03(6)$ & $0.08(21)$ \\
TTAAAA & $0.02(8)$ & $0.01(2)$ & $0.02(6)$ \\
TTAAAC & $0(2)$ & $0.01(2)$ & \\
TTAACC & $0.01(3)$ & & $0.01(3)$ \\
TTGGAA & $0.01(3)$ & & $0.01(3)$ \\
\hline
\end{tabular}

LH means Luhua chickens $(\mathrm{N}=232)$, DX means Dongxiang blue-shelled chickens $(\mathrm{N}=279)$, and ALL means the sum of the number of LH and DX $(\mathrm{N}=511)$.

Interestingly, no SNPs were associated with BWTA in either breeds or with EN in LH chickens, which are major traits of laying hens [3], but the integrated diplotype derived from the three SNPs significantly affected the two traits. A possible reason for this is positive synergy among these mutations, which may have small effects individually. This finding is consistent with previous observations of Cao et al.
[49], who found that combined genotypes had more significant effects on body weight in chicken than individual genotypes did. In DX chickens, we found that the mutations g.17156387C > T, g.17156427A $>$ G, and g.17156703A $>C$ had significant effects on partial reproductive traits, including AFE, WFE, BWTA, EWTA, and EN. These results are similar to those of some previous reports showing that GDF9 polymorphisms were associated litter size in goat [50], ovulation rate and prolificacy in sheep [24], and superovulation performance in cows [26]. Several studies are in agreement that diplotype analysis provides more information into the complex relationships between phenotypes and DNA variation $[6,51]$. In the present study, we found that certain diplotypes significantly affected AFE, BWFE and EN in laying hens. Birds with the diplotype D2 exhibited the highest EN value, and those with D7 had the lowest AFE and BWTA values. The diplotype analysis found different effect sizes of the three mutations in the chicken GDF9 gene with respect to reproductive traits. In addition, we found that laying hens with an earlier AFE had a higher EN. These results are consistent with a negative correlation between egg number and age at first egg often observed in quantitative genetics studies [1].

4.3. Expression of the GDF9 Gene in Chicken Reproductive Tissues. The GDF9 gene is expressed in human, rodent, and ruminant oocytes and is an essential factor that regulates development of ovarian follicles [17, 52, 53]. However, the expression pattern of GDF9 differs across species. For example, GDF9 expression was first reported in the primordial follicles of possum, hamsters, sheep, and cattle [19-21] and in the primary follicles of humans, mice, and rats $[22,23]$. In this study, GDF9 mRNA was found to be expressed in the STR, WF, YF, SYF, and all hierarchical follicles in chickens. These data indicate that GDF9 also plays an important role in ovary 
TABLE 9: Association analysis between GDF9 diplotypes and reproductive traits.

\begin{tabular}{|c|c|c|c|c|c|c|}
\hline & AFE (days) & BWFE (g) & WFE (g) & BWTA (g) & EWTA (g) & $\mathrm{EN}$ (count) \\
\hline \multicolumn{7}{|l|}{ Diplotype } \\
\hline D1 (CCAAAA) & $166.46 \pm 1.62^{\mathrm{a}}$ & $1673.07 \pm 31.26$ & $43.26 \pm 1.01$ & $1687.3 \pm 22.26^{\mathrm{ab}}$ & $55.66 \pm 0.66$ & $99.38 \pm 1.95^{\mathrm{ab}}$ \\
\hline D2 (CCAAAC) & $159.35 \pm 3.15^{\mathrm{bc}}$ & $1601.39 \pm 60.79$ & $39.89 \pm 1.96$ & $1627.36 \pm 43.29^{\mathrm{bc}}$ & $55.38 \pm 1.29$ & $107.21 \pm 3.79^{\mathrm{a}}$ \\
\hline D3 (CCAACC) & $165.73 \pm 2.91^{\mathrm{ab}}$ & $1753.1 \pm 56.28$ & $40.43 \pm 1.81$ & $1768.57 \pm 40.08^{\mathrm{a}}$ & $56.37 \pm 1.19$ & $102.38 \pm 3.5^{\mathrm{a}}$ \\
\hline D4 (CCAGAA) & $160.75 \pm 3.02^{\mathrm{abc}}$ & $1583.13 \pm 58.41$ & $42.11 \pm 1.88$ & $1626.67 \pm 41.6^{\mathrm{bc}}$ & $58.01 \pm 1.24$ & $106.67 \pm 3.64^{\mathrm{a}}$ \\
\hline D5 (CCAGAC) & $167.16 \pm 3.93^{\mathrm{ab}}$ & $1785 \pm 75.87$ & $41.97 \pm 2.45$ & $1666.25 \pm 54.03^{\mathrm{abc}}$ & $54.59 \pm 1.61$ & $89.84 \pm 4.72^{\mathrm{b}}$ \\
\hline D6 (CCAGCC) & $162.23 \pm 2.67^{\mathrm{abc}}$ & $1655 \pm 51.47$ & $40.86 \pm 1.66$ & $1657.06 \pm 36.65^{b c}$ & $55.49 \pm 1.09$ & $102.76 \pm 3.21^{\mathrm{a}}$ \\
\hline D7 (CTAAAA) & $155.54 \pm 2.4^{\mathrm{c}}$ & $1597.46 \pm 46.38$ & $37.28 \pm 1.49$ & $1593.77 \pm 33.03^{c}$ & $55.05 \pm 0.98$ & $103.91 \pm 2.89^{\mathrm{a}}$ \\
\hline D8 (CTAGCC) & $162.19 \pm 3.62^{\mathrm{abc}}$ & $1652.74 \pm 69.81$ & $39.17 \pm 2.25$ & $1626.19 \pm 49.72^{\mathrm{bc}}$ & $56.43 \pm 1.48$ & $99.5 \pm 4.35^{\mathrm{ab}}$ \\
\hline$P$-value & 0.01 & 0.19 & 0.08 & 0.04 & 0.66 & 0.04 \\
\hline \multicolumn{7}{|l|}{ Breed } \\
\hline $\mathrm{LH}$ & $158.4 \pm 1.33^{\mathrm{b}}$ & $1982.45 \pm 18.26^{\mathrm{a}}$ & $45.36 \pm 0.83^{\mathrm{a}}$ & $1800.59 \pm 25.64^{\mathrm{a}}$ & $61.97 \pm 0.54^{\mathrm{a}}$ & $115.66 \pm 1.6^{\mathrm{a}}$ \\
\hline DX & $166.45 \pm 1.65^{\mathrm{a}}$ & $1330.84 \pm 22.63^{b}$ & $35.89 \pm 1.02^{\mathrm{b}}$ & $1524.63 \pm 31.78^{\mathrm{b}}$ & $49.78 \pm 0.67^{b}$ & $87.01 \pm 1.98^{\mathrm{b}}$ \\
\hline$P$-value & 0.0002 & $<0.0001$ & $<0.0001$ & $<0.0001$ & $<0.0001$ & $<0.0001$ \\
\hline \multicolumn{7}{|l|}{$\mathrm{D} \times \mathrm{B}$} \\
\hline$P$-value & 0.23 & 0.94 & 0.97 & 0.94 & 0.06 & 0.76 \\
\hline
\end{tabular}

$\mathrm{N}=$ number, $\mathrm{F}=$ frequency, AFE = age at first egg, BWFE = body weight at first egg, WFE = weight of first egg, BWTA = body weight at 300 days of age, EWTA = egg weight at 300 days of age, and $\mathrm{EN}=$ total number of eggs at 300 days of age.

LH = Luhua chickens, DX = Dongxiang blue-shelled chickens.

Results are expressed as least square means \pm standard errors.

Different letters indicate significant differences $(P<0.05)$.

function and follicle development in chicken. Chicken GDF9 mRNA was most abundant in the STR and was relatively highly expressed in the WF and YF, consistent with previous studies in mammals, implying that GDF9 is responsible for early development and differentiation of the ovarian follicles $[41,43,54]$. These results indicated that GDF9 mainly affected the prehierarchal follicles in chicken. Yan et al. [17] showed that high expression level of GDF9 is one of the important conditions for maintaining the growth of a large number of ovarian follicles. Intriguingly, GDF9 expression was higher in the STR, SYF, and F6 of LH chickens than in DX counterparts. These results imply that the elevated expression of GDF9 may be related to high reproductive performance in LH chickens.

\section{Conclusion}

In this study, we detected 15 SNPs in the chicken GDG9 gene. Among these, nine SNPs were previously unreported in chicken; two (g.17156703A>C and g.17158286A>G) were missense mutations, resulting in the amino acids substitutions of Ile $\longrightarrow$ Leu and Ile $\longrightarrow$ Val, respectively; and three showed significant associations with partial reproductive traits. G.17156387C $>$ T was significantly associated with AFE and WFE in both breeds. Birds carrying the CC genotype exhibited higher AFE and WFE values than those with the TT genotype. The SNP g.17156427A $>$ G exhibited an association with EWTA in DX chickens but not LH chickens. This SNP g.17156703A>C had significant genetic effects on AFE and EN in DX hens; birds with the AA genotype had lower AFE and higher EN values compared to those with other genotypes. In addition, certain diplotypes significantly affected AFE, BWTA, and EN in both breeds. GDF9 was found to be highly expressed in the STR and all prehierarchal follicles, and its expression was increased in the STR, SYF, and F6 of $\mathrm{LH}$ chickens compared to the corresponding tissues of DX chickens. These results broadened our current understanding of the chicken GDF9 gene underlying reproductive systems and indicated that the GDF9 gene was involved in determining reproductive traits in chicken, but further studies are necessary for functional validation.

\section{Data Availability}

The data used to support the findings of this study are available from the corresponding author upon request.

\section{Conflicts of Interest}

The authors declared no conflicts of interest.

\section{Authors' Contributions}

Lingbin Liu and Qing Zhu conceived and designed the experiments, Zhifu Cui and Qihai Xiao performed the experiments, Xiaoling Zhao and Yan Wang analyzed the data, Huadong Yin and Diyan Li contributed reagents/ materials/analysis tools, Lingbin Liu wrote the paper, and Haihan Zhang and Qing Zhu revised the manuscript. Lingbin Liu, Zhifu Cui, and Qihai Xiao contributed equally to this work.

\section{Acknowledgments}

This study was financially supported by the China Agriculture Research System (CARS-41) and the China Scholarship Council (no. 201506910042). 


\section{References}

[1] A. Francesch, J. Estany, L. Alfonso, and M. Iglesias, "Genetic parameters for egg number, egg weight, and eggshell color in three catalan poultry breeds," Poultry Science, vol. 76, no. 12, pp. 1627-1631, 1997.

[2] Y. Akbaş and Ç. Takma, "Canonical correlation analysis for studying the relationship between egg production traits and body weight, egg weight and age at sexual maturity in layers," Czech Journal of Animal Science, vol. 50, no. 4, pp. 163-168, 2005.

[3] L.-B. Liu, D.-Y. Li, Z.-L. Zhao, Y.-P. Liu, Y. Wang, and Q. Zhu, "Polymorphism of Prolactin Receptor gene and its association with egg production traits in Erlang mountainous chicken," Asian Journal of Animal and Veterinary Advances, vol. 7, no. 11, pp. 1183-1190, 2012.

[4] N. Wu, Q. Zhu, B. Chen, J. Gao, Z. Xu, and D. Li, "Highthroughput sequencing of pituitary and hypothalamic microRNA transcriptome associated with high rate of egg production," BMC Genomics, vol. 18, no. 1, p. 255, 2017.

[5] M. Zhu and S. Zhao, "Candidate gene identification approach: Progress and challenges," International Journal of Biological Sciences, vol. 3, no. 7, pp. 420-427, 2007.

[6] H.-Y. Xu, Y. Wang, Y.-P. Liu, J.-W. Wang, and Q. Zhu, "Polymorphisms and expression of the chicken POU1F1 gene associated with carcass traits," Molecular Biology Reports, vol. 39, no. 8, pp. 8363-8371, 2012.

[7] Y. Zhang, H. Du, J. Chen, G. Yang, and X. Zhang, "Porcine growth differentiation factor 9 gene polymorphisms and their associations with litter size," Journal of Genetics and Genomics, vol. 35, no. 3, pp. 163-169, 2008.

[8] M. X. Chu, Z. H. Wu, T. Feng et al., "Polymorphism of GDF9 gene and its association with litter size in goats," Veterinary Research Communications, vol. 35, no. 6, pp. 329-336, 2011.

[9] D. I. Våge, M. Husdal, M. P. Kent, G. Klemetsdal, and I. A. Boman, "A missense mutation in growth differentiation factor 9 (GDF9) is strongly associated with litter size in sheep," $B M C$ Genetics, vol. 14, article no. 1, 2013.

[10] M. A. R. Howlider, T. Yeasmin, and M. U. Ahammad, "Effect of introgressing dwarf gene from Bangladeshi indigenous to exotic breeds on egg production," International Journal of Poultry Science, vol. 2, no. 4, pp. 264-266, 2003.

[11] A.-S. Van Laere, M. Nguyen, M. Braunschweig et al., "A regulatory mutation in IGF2 causes a major QTL effect on muscle growth in the pig," Nature, vol. 425, no. 6960, pp. 832-836, 2003.

[12] P. L. Johnson, J. C. McEwan, K. G. Dodds, R. W. Purchas, and H. T. Blair, "A directed search in the region of GDF8 for quantitative trait loci affecting carcass traits in Texel sheep," Journal of Animal Science, vol. 83, no. 9, pp. 1988-2000, 2005.

[13] B. Grisart, W. Coppieters, F. Farnir et al., "Positional candidate cloning of a QTL in dairy cattle: identification of a missense mutation in the bovine DGAT1 gene with major effect on milk yield and composition," Genome Research, vol. 12, no. 2, pp. 222231, 2002.

[14] G. Thaller, C. Kühn, A. Winter et al., "DGAT1, a new positional and functional candidate gene for intramuscular fat deposition in cattle," Animal Genetics, vol. 34, no. 5, pp. 354-357, 2003.

[15] J. L. Juengel and K. P. McNatty, “The role of proteins of the transforming growth factor- $\beta$ superfamily in the intraovarian regulation of follicular development," Human Reproduction Update, vol. 11, no. 2, pp. 143-160, 2005.
[16] A. M. C. V. Alves, R. N. Chaves, R. M. P. Rocha et al., "Dynamic medium containing growth differentiation factor9 and FSH maintains survival and promotes in vitro growth of caprine preantral follicles after long-term in vitro culture," Reproduction, Fertility and Development, vol. 25, no. 6, pp. 955965, 2013.

[17] C. Yan, P. Wang, J. Demayo et al., "Synergistic roles of bone morphogenetic protein 15 and growth differentiation factor 9 in ovarian function," Molecular Endocrinology, vol. 15, no. 6, pp. 854-866, 2001

[18] K. P. McNatty, J. L. Juengel, K. L. Reader et al., "Bone morphogenetic protein 15 and growth differentiation factor 9 co-operate to regulate granulosa cell function," Reproduction, vol. 129, no. 4, pp. 473-480, 2005.

[19] D. C. Eckery, L. J. Whale, S. B. Lawrence, K. A. Wylde, K. P. McNatty, and J. L. Juengel, "Expression of mRNA encoding growth differentiation factor 9 and bone morphogenetic protein 15 during follicular formation and growth in a marsupial, the brushtail possum (Trichosurus vulpecula)," Molecular and Cellular Endocrinology, vol. 192, no. 1-2, pp. 115-126, 2002.

[20] J. Wang and S. K. Roy, "Growth differentiation factor-9 and stem cell factor promote primordial follicle formation in the hamster: modulation by follicle-stimulating hormone," Biology of Reproduction, vol. 70, no. 3, pp. 577-585, 2004.

[21] K. J. Bodensteiner, C. M. Clay, C. L. Moeller, and H. R. Sawyer, "Molecular cloning of the ovine growth/differentiation factor-9 gene and expression of growth/differentiation factor-9 in ovine and bovine ovaries," Biology of Reproduction, vol. 60, no. 2, pp. 381-386, 1999.

[22] J. Aaltonen, M. P. Laitinen, K. Vuojolainen et al., "Human growth differentiation factor 9 (GDF-9) and its novel homolog GDF-9B are expressed in oocytes during early folliculogenesis," The Journal of Clinical Endocrinology \& Metabolism, vol. 84, no. 8, pp. 2744-2750, 1999.

[23] M. Laitinen, K. Vuojolainen, R. Jaatinen et al., "A novel growth differentiation factor-9 (GDF-9) related factor is co- expressed with GDF-9 in mouse oocytes during folliculogenesis," Mechanisms of Development, vol. 78, no. 1-2, pp. 135-140, 1998.

[24] B. D. M. Silva, E. A. Castro, C. J. H. Souza et al., "A new polymorphism in the Growth and Differentiation Factor 9 (GDF9) gene is associated with increased ovulation rate and prolificacy in homozygous sheep," Animal Genetics, vol. 42, no. 1, pp. 89-92, 2011.

[25] X. P. An, J. X. Hou, and H. B. Zhao, "Polymorphism identification in goat GNRH1 and GDF9 genes and their association analysis with litter size," Animal Genetics, vol. 44, no. 2, pp. 234238, 2013.

[26] K. Q. Tang, W. C. Yang, S. J. Li, and L.-G. Yang, "Polymorphisms of the bovine growth differentiation factor 9 gene associated with superovulation performance in Chinese Holstein cows," Genetics and Molecular Research, vol. 12, no. 1, pp. 390-399, 2013.

[27] K. Q. Tang, W. C. Yang, X. X. Zhang, and L. G. Yang, "Effects of polymorphisms in the bovine growth differentiation factor 9 gene on sperm quality in Holstein bulls," Genetics and Molecular Research, vol. 12, no. 3, pp. 2189-2195, 2013.

[28] K. M. Weiss and J. D. Terwilliger, "How many diseases does it take to map a gene with SNPs?" Nature Genetics, vol. 26, no. 2, pp. 151-157, 2000.

[29] D. van Inghelandt, A. E. Melchinger, C. Lebreton, and B. Stich, "Population structure and genetic diversity in a commercial maize breeding program assessed with SSR and SNP markers," 
Theoretical and Applied Genetics, vol. 120, no. 7, pp. 1289-1299, 2010.

[30] W. K. Ruan, Y. H. Wu, J. An, D. F. Cui, H. R. Li, and S. J. Zheng, "Toll-like receptor 2 type 1 and type 2 polymorphisms in different chicken breeds," Poultry Science, vol. 91, no. 1, pp. 101106, 2012.

[31] X.-T. Wang, X. Deng, C.-J. Zhao et al., "Study of the deposition process of eggshell pigments using an improved dissolution method," Poultry Science, vol. 86, no. 10, pp. 2236-2238, 2007.

[32] X. L. Wang, J. X. Zheng, Z. H. Ning, L. J. Qu, G. Y. Xu, and N. Yang, "Laying performance and egg quality of blue-shelled layers as affected by different housing systems," Poultry Science, vol. 88, no. 7, pp. 1485-1492, 2009.

[33] L. Liu, D. Li, E. R. Gilbert et al., "Effect of monochromatic light on expression of estrogen receptor (ER) and progesterone receptor (PR) in ovarian follicles of Chicken," PLOS ONE, vol. 10, no. 12, Article ID 0144102, 2015.

[34] D. Y. Li, L. Zhang, M. Y. Yang et al., "Effect of luteinizing hormone/choriogonadotropin receptor (LHCGR) gene on chicken reproductive traits," Molecular Biology Reports, vol. 40, no. 12, pp. 7111-7116, 2013.

[35] D. Y. Li, L. Zhang, D. G. Smith et al., "Genetic effects of melatonin receptor genes on chicken reproductive traits," Czech Journal of Animal Science, vol. 58, no. 2, pp. 58-64, 2013.

[36] L. Liu, Q. Xiao, E. R. Gilbert et al., "Whole-transcriptome analysis of atrophic ovaries in broody chickens reveals regulatory pathways associated with proliferation and apoptosis," Scientific Reports, vol. 8, no. 1, 2018.

[37] J. C. Barrett, B. Fry, J. Maller, and M. J. Daly, "Haploview: analysis and visualization of LD and haplotype maps," Bioinformatics, vol. 21, no. 2, pp. 263-265, 2005.

[38] M. Stephens, N. J. Smith, and P. Donnelly, "A new statistical method for haplotype reconstruction from population data," American Journal of Human Genetics, vol. 68, no. 4, pp. 978989, 2001.

[39] L. Liu, G. Wang, and Y. Xiao, "Peripheral neuropeptide Y differentially influences adipogenesis and lipolysis in chicks from lines selected for low or high body weight," Comparative Biochemistry and Physiology Part A: Molecular Integrative Physiology, vol. 213, p. 10, 2017.

[40] J. P. Hanrahan, S. M. Gregan, P. Mulsant et al., "Mutations in the genes for oocyte-derived growth factors gdf9 and bmp15 are associated with both increased ovulation rate and sterility in cambridge and belclare sheep (ovis aries)," Biology of Reproduction, vol. 70, no. 4, pp. 900-909, 2004.

[41] S. A. Pangas and M. M. Matzuk, "The art and artifact of GDF9 activity: Cumulus expansion and the cumulus expansionenabling factor," Biology of Reproduction, vol. 73, no. 4, pp. 582585, 2005.

[42] P. Laissue, S. Christin-Maitre, P. Touraine et al., "Mutations and sequence variants in GDF9 and BMP15 in patients with premature ovarian failure," European Journal of Endocrinology, vol. 154, no. 5, pp. 739-744, 2006.

[43] Y.-Q. Su, K. Sugiura, K. Wigglesworth et al., "Oocyte regulation of metabolic cooperativity between mouse cumulus cells and oocytes: BMP15 and GDF9 control cholesterol biosynthesis in cumulus cells," Development, vol. 135, no. 1, pp. 111-121, 2008.

[44] C. Dong and L. Du, "Research on polymorphism analysis of GDF9 gene related to reproduction trait of goat," Journal of Shandong Agricultural University (Natural Science Edition), vol. 2, p. 16, 2011.
[45] S. Varani, J. A. Elvin, C. Yan et al., "Knockout of pentraxin 3, a downstream target of growth differentiation factor-9, causes female subfertility," Molecular Endocrinology, vol. 16, no. 6, pp. 1154-1167, 2002.

[46] K. P. McNatty, S. M. Galloway, T. Wilson et al., "Physiological effects of major genes affecting ovulation rate in sheep," Genetics Selection Evolution, vol. 37, no. 1, pp. S25-S38, 2005.

[47] J. S. Palmer, Z. Z. Zhao, C. Hoekstra et al., "Novel variants in growth differentiation factor 9 in mothers of dizygotic twins," The Journal of Clinical Endocrinology Metabolism, vol. 91, no. 11, pp. 4713-4716, 2006.

[48] J. E. F. Butler and J. T. Kadonaga, "The RNA polymerase II core promoter: A key component in the regulation of gene expression," Genes \& Development, vol. 16, no. 20, pp. 25832592, 2002.

[49] Z. P. Cao, S. Z. Wang, Q. G. Wang, Y. X. Wang, and H. Li, "Association of Spot14 $\alpha$ gene polymorphisms with body weight in the chicken," Poultry Science, vol. 86, no. 9, pp. 1873-1880, 2007.

[50] T. Feng, C. X. Geng, X. Z. Lang et al., "Polymorphisms of caprine GDF9 gene and their association with litter size in Jining Grey goats," Molecular Biology Reports, vol. 38, no. 8, pp. 5189-5197, 2011.

[51] A. Jansen, S. Krach, A. Krug et al., "A putative high risk diplotype of the G72 gene is in healthy individuals associated with better performance in working memory functions and altered brain activity in the medial temporal lobe," NeuroImage, vol. 45, no. 3, pp. 1002-1008, 2009.

[52] U. A. Vitt, E. A. McGee, M. Hayashi, and A. J. W. Hsueh, "In vivo treatment with GDF-9 stimulates primordial and primary follicle progression and theca cell marker CYP17 in ovaries of immature rats," Endocrinology, vol. 141, no. 10, pp. 3814-3820, 2000.

[53] J. G. Hreinsson, J. E. Scott, C. Rasmussen, M. L. Swahn, A. J. W. Hsueh, and O. Hovatta, "Growth differentiation factor-9 promotes the growth, development, and survival of human ovarian follicles in organ culture," The Journal of Clinical Endocrinology \& Metabolism, vol. 87, no. 1, pp. 316-321, 2002.

[54] S. Mazerbourg, C. Klein, J. Roh et al., "Growth differentiation factor-9 signaling is mediated by the type I receptor, activin receptor-like kinase 5," Molecular Endocrinology, vol. 18, no. 3, pp. 653-665, 2004. 


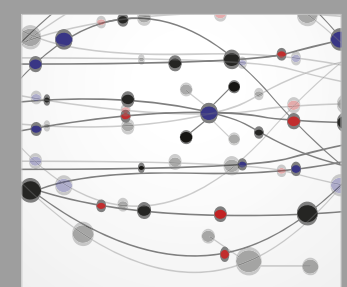

The Scientific World Journal
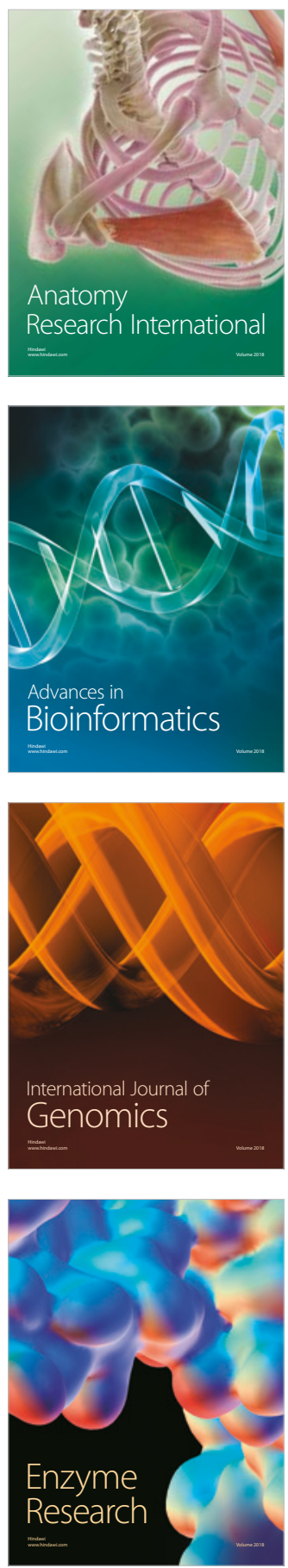
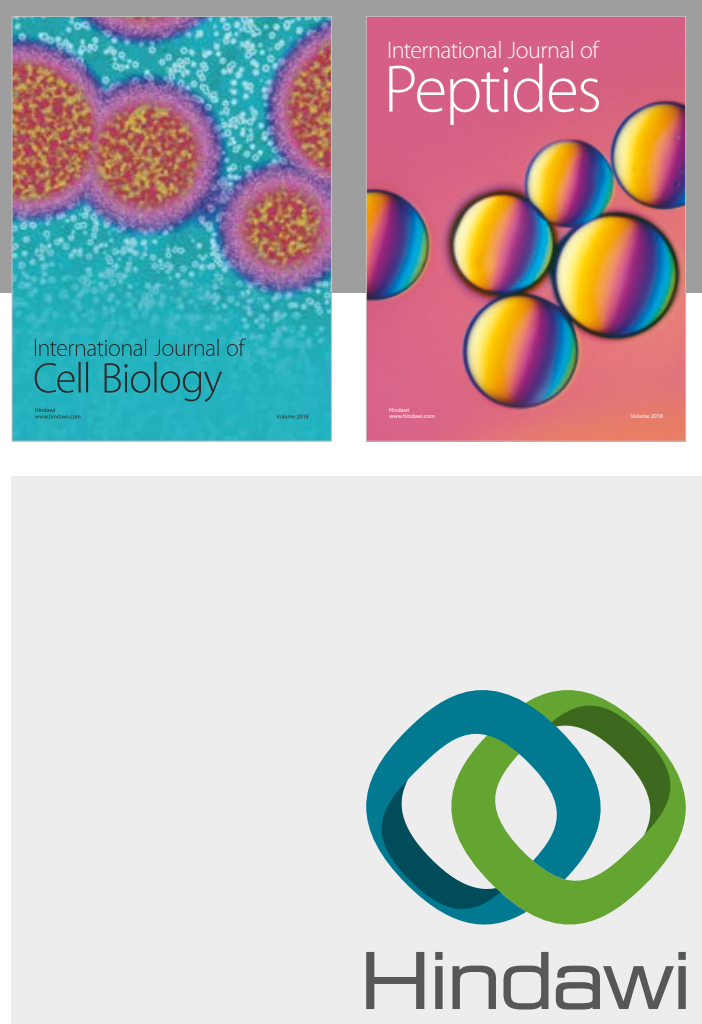

Submit your manuscripts at

www.hindawi.com
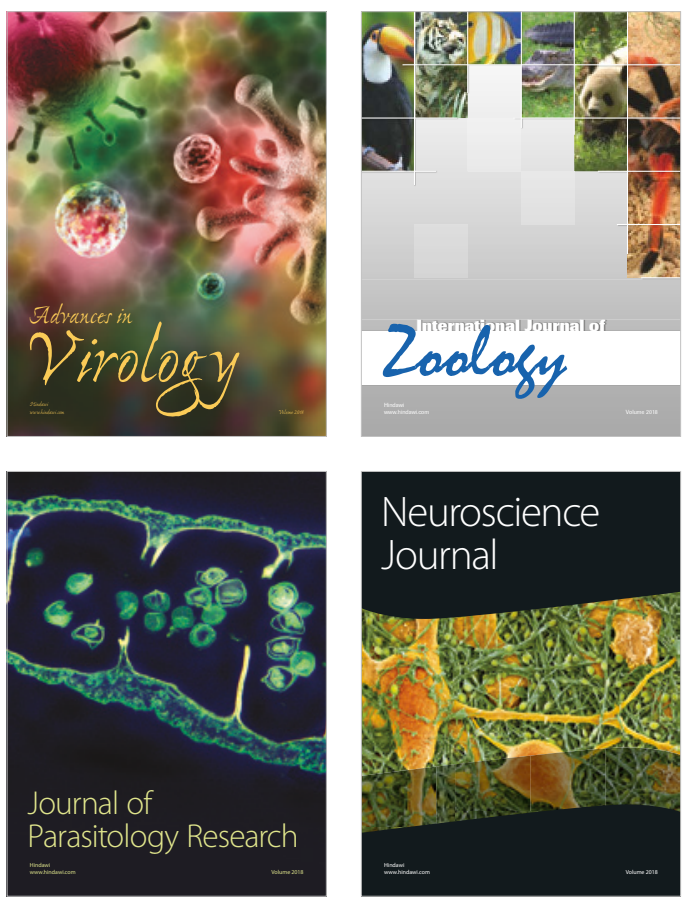


nternational Journal of Microbiology
Journal of
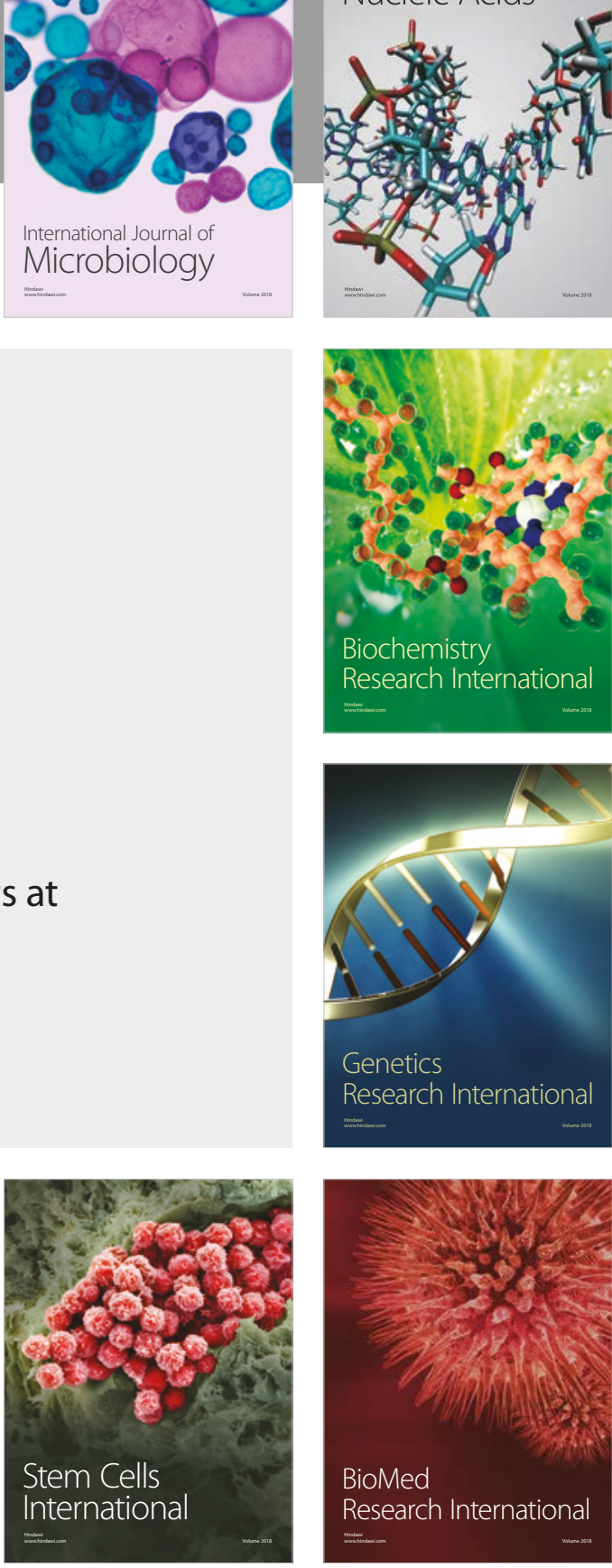
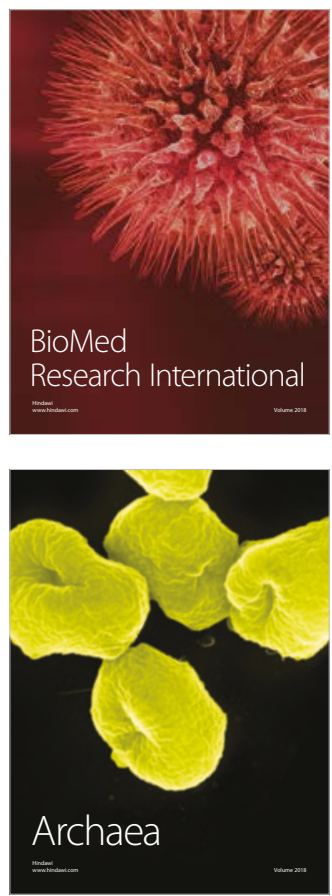